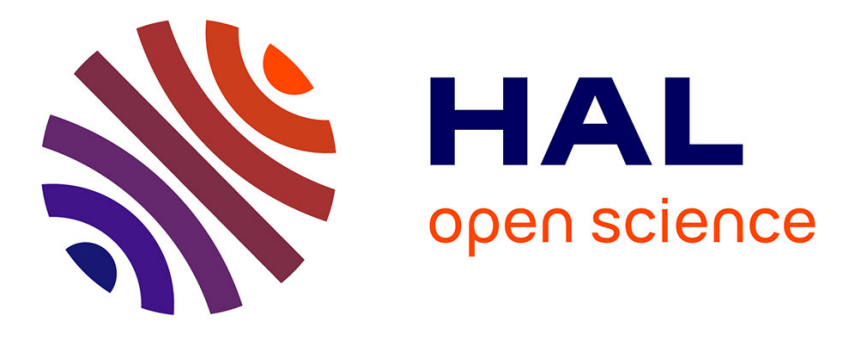

\title{
Morphological Processing across Modalities and Languages
}

Elisabeth Beyersmann, Petroula Mousikou, Ludivine Javourey-Drevet, Sascha Schroeder, Johannes Ziegler, Jonathan Grainger

\section{To cite this version:}

Elisabeth Beyersmann, Petroula Mousikou, Ludivine Javourey-Drevet, Sascha Schroeder, Johannes Ziegler, et al.. Morphological Processing across Modalities and Languages. Scientific Studies of Reading, 2020, 24 (6), pp.500-519. 10.1080/10888438.2020.1730847 . hal-02991231

\section{HAL Id: hal-02991231 https://hal-amu.archives-ouvertes.fr/hal-02991231}

Submitted on 24 Dec 2020

HAL is a multi-disciplinary open access archive for the deposit and dissemination of scientific research documents, whether they are published or not. The documents may come from teaching and research institutions in France or abroad, or from public or private research centers.
L'archive ouverte pluridisciplinaire HAL, est destinée au dépôt et à la diffusion de documents scientifiques de niveau recherche, publiés ou non, émanant des établissements d'enseignement et de recherche français ou étrangers, des laboratoires publics ou privés. 


\section{Morphological processing across modalities and languages}

Elisabeth Beyersmann*1, Petroula Mousikou*2,5, Ludivine Javourey-Drevet ${ }^{3,4}$, Sascha Schroeder ${ }^{2,5}$, Johannes C. Ziegler ${ }^{3,6}$, \& Jonathan Grainger ${ }^{3,6}$

${ }^{1}$ Department of Cognitive Science and Macquarie Centre for Reading, Macquarie University, Sydney, Australia

${ }^{2}$ Max Planck Institute for Human Development, Berlin, Germany

${ }^{3}$ Laboratoire de Psychologie Cognitive, Aix-Marseille University and Centre National de la Recherche Scientifique, Marseille, France

${ }^{4}$ Laboratoire Apprentissage, Didactique, Évaluation, Formation, Aix-Marseille Université, Marseille, France

${ }^{5}$ Department of Educational Psychology, University of Göttingen, Göttingen, Germany

${ }^{6}$ Institute for Language, Communication, and the Brain, Aix-Marseille University, Marseille,

France

Author Note

*E.B. and P.M. contributed equally to this work.

Correspondence concerning this article should be addressed to Elisabeth Beyersmann, Department of Cognitive Science, Australian Hearing Hub, 16 University Avenue, Macquarie University NSW 2109, Tel: +61 406 249 916, Email: $\underline{\text { lisi.beyersmann@mq.edu.au }}$ 


\begin{abstract}
The present study examined cross-linguistic differences in morphological processing in the visual and auditory modality. French and German adults performed a visual and auditory lexical decision task that involved the same translation-equivalent items. The focus of the study was on nonwords, which were constructed in a way that the independent role of stems and suffixes in visual and auditory processing could be investigated. Results revealed a stem-by-modality and a suffix-by-modality interaction, indicating a more prominent role for morphology in the visual than in the auditory domain. Moreover, a significant language-by-stem interaction indicated more robust morphological processing in German than in French. The latter result supports the idea that morphological processing is influenced by the morphological productivity of a language.
\end{abstract}

Keywords: morphological processing, cross-linguistic, visual lexical decision; auditory lexical decision 
How morphologically complex words are processed has been extensively investigated over the past few decades. However, few studies have investigated this issue across languages and modalities. The present study was designed to address two questions that have so far received little attention in the literature. The first question concerns if and how mechanisms of morphological processing differ depending on whether the input stimulus is a printed letter string or a speech signal. The second question asks how these mechanisms might differ across languages that vary in morphological productivity. Addressing these questions has the potential to advance theories of morphological processing by providing a broader modality-independent and language-universal perspective. The present study uses an innovative approach to answer each of these questions.

\section{Morphological processing across modalities}

In many Indo-European languages with concatenative morphology, sound-to-meaning mappings of morphologically complex words are typically less consistent than spelling-tomeaning mappings (e.g., Berg \& Aronoff, 2017; Berg, Buchmann, Dybiec, \& Fuhrhop, 2014; Rastle, 2018; Ulicheva, Harvey, Aronoff, \& Rastle, 2018). For instance, in spoken English, the past tense is usually denoted by the allomorphs /əd/, /d/, or /t/ depending on surrounding context (e.g., busted, snored, kicked), whereas in written English, the corresponding phonemic sequences are always spelled ed (e.g., Carney, 1994; Desrochers, Manolitsis, Gaudreau, \& Georgiou, 2017; Rastle, 2018). Similarly, the spelling of stems is preserved (e.g., magic, magical, magician), although this compromises the correspondence to their spoken forms (Treiman \& Bourassa, 2000). The greater orthographic consistency of morphology in the written modality at the cost of spelling-to-sound consistency is also evident in German and French (e.g., Desrochers et al., 2017; Kuo \& Anderson, 2006; Peereman, Sprenger-Charolles, \& Messaoud-Galusi, 2013). In 
German, for example, the written form of morphologically related words (e.g., Sand-sandig, "sand-sandy") is preserved even when the spoken form varies (/zant//zandik/), where the ' $\mathrm{d}$ ' in 'Sand' is pronounced /t/ due to devoicing (see also Landerl \& Reitsma, 2005). Similarly in French, the spellings of morphologically complex words and their embedded stems are typically consistent (e.g. dent-dentier, "tooth-dentist"), whereas phonological forms tend to be more variable (e.g., the silent stem-final consonant ' $t$ ' in 'dent' is pronounced when a suffix is added to the stem). The consistent spelling of morphemes enables the reader to identify morphological relationships between words, although the pronunciations of words belonging to the same morphological family may vary. Diachronic data on the evolution of suffix spellings from Old English indeed show that before the $16^{\text {th }}$ Century, adjectives were commonly spelled with the suffixes -ouse, -us, or -ows, but were then replaced with -ous over time (Berg \& Aronoff, 2017), thus making morphology highly visible in print (see Fuhrhop, 2011, for a similar phenomenon in German).

Of course, this does not necessarily imply that auditory and visual morphological representations in languages such as English, German and French are unrelated. There is plenty of evidence that spoken word knowledge influences reading processes (e.g., Beyersmann et al., in press; Johnston, McKague, \& Pratt, 2004; McKague, Davis, Pratt, \& Johnston, 2008; Wegener et al., 2018); and vice versa, it has been shown that reading has an impact on the processing of spoken language (for a review of the evidence, see Grainger \& Ziegler, 2008; see also Pollatsek \& Treiman, 2015). Undoubtedly, there is an obvious transfer of written language knowledge to spoken language processing and vice versa (e.g., Frost \& Ziegler, 2007). However, given the greater consistency of morphology in print, it is possible that skilled readers acquire a specialized and highly automatized morphological parsing system, which is sensitive to the presence of 
morphological regularities during orthographic exposure. In spoken language on the other hand, morphological processing is unlikely to reach the same level of specialization, at least in languages where the link between morphologically complex spoken forms and their embedded morphemic constituents is often inconsistent, and as such, the identification of morphological structure is less reliable. Therefore, an important question that arises is whether morphological processing is more prominent and more automatized in written compared to spoken word recognition. We sought to answer this question in the present study.

Most studies to date have examined morphological processing either in written or in spoken language using a variety of experimental paradigms (for a recent review of the literature, see Beyersmann et al., 2019). However, rarely has a study directly compared morphological processing in the visual and auditory modality. Findings from the visual word recognition domain suggest that adults are experts at rapidly and automatically identifying morphological structures in print, independently of semantics (e.g., Amenta \& Crepaldi, 2012; Beyersmann, Ziegler, et al., 2016; Longtin, Segui, \& Hallé, 2003; Rastle \& Davis, 2008; Rastle, Davis, \& New, 2004). In contrast, a review of the spoken word recognition literature (Beyersmann et al., 2019) indicates that morphological processing may be more reliant on semantics in this modality (Marslen-Wilson, Tyler, Waksler, \& Older, 1994; Meunier \& Longtin, 2007; Wurm, 1997, 2000; Wurm \& Ross, 2001). In other words, on the basis of the available empirical evidence, formbased morphological processing is likely to be more prominent in visual than in auditory word identification.

To our knowledge, only one study so far has directly tested differences in morphological processing between the spoken and written modality (Leinonen et al., 2009). In a visual and auditory lexical decision task, in which event-related potentials (ERPs) were additionally 
recorded, Leinonen et al. (2009) sought to investigate the processing of inflected Finnish words (compared to monomorphemic words) and inflected nonwords consisting of a nonword stem and an inflectional suffix (compared to monomorphemic nonwords consisting of a nonword stem and a non-morphemic ending). The behavioral results from both types of tasks showed that participants responded more slowly to inflected words compared to monomorphemic words, but there was no difference between the two types of nonwords. This pattern was also reflected in the ERP analyses, where inflected words elicited a more negative N400 compared to monomorphemic words. The single word N400 component is generally thought to reflect word form processing difficulty (e.g., Perre, Midgley, \& Ziegler, 2009; Winsler, Midgley, Grainger, \& Holcomb, 2018), with N400 amplitude increasing with an increased difficulty in identifying words and associating them with meaning (e.g., Grainger \& Holcomb, 2009). The greater N400 for inflected words compared to monomorphemic ones was obtained in both modalities, which the authors interpreted as processing costs associated with access and possible integration of the stem and suffix. Leinonen et al. (2009) also reported a significant N400 effect in the inflected nonwords relative to their monomorphemic nonword counterparts, which was significant in the visual but not in the auditory modality. Thus, the ERP results from this study provide some initial evidence that morphological structure may have more impact on visual than on auditory processing.

Morphological processing across languages

Given that Finnish is a morphologically productive language, it is possible that the effects observed by Leinonen et al. (2009) were due to the prominent role of morphology in Finnish. This relates to the second question we addressed in this study, which is whether morphological processing in the visual and auditory modality may be modulated by the morphological 
productivity of a language. Morphological productivity refers to how specific morphological word-formation patterns may be used in the production of new forms (Bauer, 2001). Morphemic units (including both affixes and stem morphemes) display large variability in morphological productivity (Hay \& Baayen, 2002). The more often a morpheme occurs in morphologically complex forms in the lexicon, the more productive this morpheme is thought to be. Critically, languages differ in this respect, and attempts to quantify morphological productivity across different alphabetic orthographies (for a review, see Borleffs, Maassen, Lyytinen, \& Zwarts, 2017) have not always yielded a consistent pattern of results. However, according to at least two of the methods used in the literature, namely, Juola $(1998,2008)$, and the most recent and comprehensive Type-token ratio (TTR; Kettunen, 2014), French is morphologically less complex than German. It has been suggested that the abundant presence of compound words in the German language (e.g., Creutz \& Lagus, 2005; Creutz, Lagus, Lindén, \& Virpioja, 2005; Fleischer \& Barz, 1995; Meyer, 1993) may be the reason why according to the above-mentioned methods, German appears to be so morphologically complex (Sadeniemi, Kettunen, LindhKnuutila, \& Honkela, 2008). German compounds are mostly right-headed and concatenated (Großvater [engl. grandfather]), whereas French compounds are typically left-headed and nonconcatenated (chef de police [engl. chief of police]) or hyphenated (grand-père [engl. grandfather]) (Nicoladis \& Krott, 2007). The latter type is less frequent than the former and not very productive (Nicoladis, 2001). German also permits the compounding of multiple meaning conveying units (e.g. Datenschutzexpertentagungshotel [engl. Meeting hotel for data protection experts]), which are generally written without intervening spaces (e.g., Inhoff, Radach, \& Heller, 2000). Given these key linguistic differences between French and German, we hypothesized that morphological processing should be more robust in German than in French. Specifically, due to 
the rich compounding system that characterizes the German language, Germans should likely be more expert at rapidly extracting embedded stem morphemes from fully concatenated complex forms. As opposed to affixes, stems are free-standing morphemes that can be mapped onto existing representations in the mental lexicon and therefore do not require a specialized morphological chunking mechanism (Grainger \& Beyersmann, 2017). Grainger and Beyersmann (2017) therefore argue that the mechanism by which stems are recognized is distinct from the mechanism by which affixes are being identified. Given their high exposure to compound words, we reasoned that Germans might develop certain proficiency at mapping embedded stems onto existing lexical representations, which will likely be reflected in more robust stem-identification effects in German than in French.

\section{Present study}

To test differences in morphological processing between the visual and auditory modality in French and German we used an experimental paradigm that allowed us to tightly control for both item- and language-specific variables. We conducted an auditory and a visual lexical decision task using the same translation-equivalent items in both tasks. We focused on the processing of morphologically complex nonwords by manipulating orthogonally the stem and the suffix. In particular, four conditions were created: Stem + Suffix (e.g., nuit + eur $=$ nuiteur, Nacht + er $=$ Nachter $[$ engl. nighter] $)$, Stem + Non-Suffix (e.g., nuit + erge $=$ nuiterge, Nacht + $a t z=$ Nachtatz; where erge and atz are non-morphemic endings in French and German, respectively [engl. nightel]), Non-Stem + Suffix (e.g., nait + eur $=$ naiteur, Necht + er $=$ Nechter; where nait and Necht are nonwords [engl. naghter]), and Non-Stem + Non-Suffix (e.g., nait + erge $=$ naiterge, $N e c h t+a t z=$ Nechtatz $[$ engl. naghtel] $)$. The primary advantage of this $2 \times 2$ design was that it allowed to tease apart the separate roles of the stem and the suffix, as well 
as their interactions. The selection of nonwords provided greater control over psycholinguistic variables that are known to influence language processing (e.g., word frequency).

\section{Previous studies}

It is worth noting that a number of studies in this research domain have included complex nonwords in their investigations, but these have been typically restricted to the comparison between Non-Stem + Affix vs. Non-Stem + Non-Affix (Lavric, Elchlepp, \& Rastle, 2012; Zweig \& Pylkkänen, 2009), Stem + Affix vs. Non-Stem + Affix (Taft \& Forster, 1975), Non-Stem + Suffix vs. Non-Stem + Non-Suffix vs. Stem + Non-Suffix (Vannest, Newport, Newman, \& Bavelier, 2011), or Stem + Suffix vs. Stem + Non-Suffix (Beyersmann et al., 2019; Dawson, Rastle, \& Ricketts, 2018). What these prior studies concurrently show is that the presence of morphemes in nonwords makes the process of rejecting a nonword in lexical decision harder, a finding that has been typically referred to as the "morpheme interference effect" (Taft \& Forster, 1975). However, what these studies were less able to address are the combined effects of stem and affix, because of the absence of a full factorial design.

\section{Hypotheses}

In sum, the present study investigated how morphological processing might differ in the visual and auditory modality as a function of the morphological productivity of a language. We hypothesized that a suffix-effect would be evidenced by slower reaction times (RTs) and higher error rates in the Suffix compared to the Non-Suffix conditions, whereas a stem-effect would be evidenced by slower RTs and higher error rates in the Stem compared to the Non-Stem conditions. This is because the presence of a suffix and/or a stem in nonwords should make their rejection harder during lexical decision. The combined stem- and suffix-effects should further result in a significant Stem-by-Suffix interaction, because the stem-effect would be larger for 
suffixed than for non-suffixed nonwords. We also expected more robust stem- and suffix-effects in the visual compared to the auditory modality (i.e., evidenced by significant Stem-by-Modality and Suffix-by-Modality interactions), because morphological structure is more consistently represented in print than aurally. Moreover, on the assumption that the morphological productivity of a language influences the degree of morphological processing both visually and aurally, we hypothesized that morphological processing, and in particular embedded stem recognition, should be more robust in German than in French (i.e., evidenced by a robust Language-by-Stem interaction). On the assumption that morphological productivity in German is attributed to its rich compounding rather than its derivational system (Sadeniemi et al., 2008), it was less clear whether a Language-by-Suffix interaction would also emerge. If anything, this should be weaker or smaller in size than the Language-by-Stem interaction. Finally, as a byproduct of our key hypotheses listed above, it was further predicted that the additive weight of the larger morphology effects in the visual modality, and the larger morphology effects in the German language, would result in an overall larger modality effect in German (evidenced by a significant Language-by-Modality interaction), as well as larger morphology effects in the visual modality in German (evidenced by a significant Language-by-Modality-by-Stem interaction, and possibly a significant Language-by-Modality-by-Suffix interaction).

\section{Experiment}

\section{Method}

Participants. A total of 96 adults, 48 French (4 males, 5 right-handed, Mean Age $=19.0$, $\mathrm{SD}=1.7)$ and 48 German (11 males, 5 left-handed, Mean Age $=24.7, \mathrm{SD}=3.8)$ participated in the study for monetary compensation. Participants were native speakers of their respective language, had normal or corrected-to-normal vision, and reported no hearing, reading, or 
language difficulties. Five French participants were bilingual (French-Italian, French-Portuguese, or French-English) and one was trilingual (French-Malagasy-English). Two German participants were bilingual (German-English, German-Bulgarian). The study was approved by the ethics committees of Aix-Marseille Université and the Max Planck Institute for Human Development, for the French and German participants, respectively. Prior to participating in the study, participants provided written, informed consent. Each participant completed both the visual and the auditory lexical decision task, while the order of the tasks was counterbalanced across participants.

Materials. Sixty morphologically simple words corresponding to translation-equivalent nouns (e.g., nuit, Nacht [engl. night]), which often happened to be cognates (e.g., film), were selected from each language. These 60 words served as stems and were combined with five noun-forming, translation-equivalent suffixes in the two languages to form morphologically structured and non-morphologically structured nonword targets (see Table 1 for details concerning the selected suffixes). The French and German suffixes were matched as clozely as possible on number of letters $(M=3.6, S D=0.5$ vs. $M=3.4, S D=0.6 ; t(4)=0.54, p=.621)$, number of phonemes $(M=2.0, S D=0.6$ vs. $M=2.8, S D=0.6 ; t(4)=1.37, p=.242)$, and logarithmic suffix frequency ${ }^{1}(M=3.2, S D=0.3$ vs. $M=2.9, S D=0.5 ; t(4)=2.43, p=.072)$, for French and German, respectively.

\footnotetext{
${ }^{1}$ Suffix frequencies were extracted from CELEX (Baayen, Piepenbrock, \& van Rijn, 1993) for German and Lexique (New, Pallier, Brysbaert, \& Ferrand, 2004) for French. We note however that the suffix frequency measures for the two languages are not directly comparable, because the size of the corresponding corpora and the morphological segmentation methods that were used in each case differed.
} 
Table 1. Translation equivalent French and German suffixes and their meanings.

\begin{tabular}{|c|c|c|c|c|}
\hline German & French & English* & Examples (German; French) & Suffix meaning \\
\hline ung & ion & ion & $\begin{array}{l}\text { Trennung; separation } \\
\text { (Engl. separation) }\end{array}$ & $\begin{array}{l}\text { (result of) an action or } \\
\text { process }\end{array}$ \\
\hline bar & able & able & $\begin{array}{l}\text { ersetzbar; remplaçable } \\
\text { (Engl. replaceable) }\end{array}$ & $\begin{array}{l}\text { able to be done; } \\
\text { suitable; subject to }\end{array}$ \\
\hline keit & ment & ment & $\begin{array}{l}\text { Dankbarkeit, remerciement } \\
\text { (Engl. acknowledgement) }\end{array}$ & $\begin{array}{l}\text { action or result of what } \\
\text { is denoted by the stem }\end{array}$ \\
\hline er & eur & er & $\begin{array}{l}\text { Arbeiter, travailleur } \\
\text { (Engl. worker) }\end{array}$ & $\begin{array}{l}\text { forms agent nouns from } \\
\text { the stem }\end{array}$ \\
\hline haft & eux & ful & $\begin{array}{l}\text { Zweifelhaft; douteux } \\
\text { (Engl. doubtful) }\end{array}$ & $\begin{array}{l}\text { possessing the quality } \\
\text { expressed by the stem }\end{array}$ \\
\hline
\end{tabular}

*English translations are provided for reporting purposes only.

Stems were either combined with suffixes, forming nonwords in the Stem + Suffix condition (e.g., nuiteur, Nachter [engl. nighter]), or a letter sequence that did not correspond to a suffix, forming nonwords in the Stem + Non-Suffix condition (e.g., nuiterge, Nachtatz [engl. nightel]). After a letter was replaced in these stems, the resulting non-stems (i.e., nonwords) were combined with the same suffixes, forming nonwords in the Non-Stem + Suffix condition (e.g., naiteur, Nechter [engl. naghter]), or the same letter sequences, forming nonwords in the NonStem + Non-Suffix condition (e.g., naiterge, Nechtatz [engl. naghtel]). In addition, sixty words that also corresponded to translation-equivalent nouns in the two languages were selected and included in the study for the purpose of the lexical decision task. Half of these words, which often happened to be cognates too, were suffixed, hence morphologically complex (e.g., boulanger, Bäcker [engl. baker]), while the remaining half were non-affixed (e.g., diamant, Diamant [engl. diamond]), hence morphologically simple. ${ }^{2}$

\footnotetext{
${ }^{2}$ Due to an oversight, three German non-suffixed words (Bescheid, Existenz, Frisur) were originally incorrectly chosen as suffixed. However, for the calculation of the psycholinguistic properties of the items and the analyses, these items were classified as non-suffixed.
} 
Word frequency and Orthographic Levenshtein distance (OLD20: Yarkoni, Balota, \& Yap, 2008), were extracted from Lexique (New et al., 2004) for French, and SUBTLEX-DE (Brysbaert et al., 2011) for German, both of which use film subtitles to calculate word frequencies. ${ }^{3}$ The OLD20 is given by the number of edits (insertions, deletions, and substitutions) required to transform one word into another, and is based on the average edit distance of the 20 nearest neighbors in the lexicon. The higher the OLD20 value of a word or a nonword, the sparser its orthographic neighborhood. All items are shown in the Appendix and their psycholinguistic properties are displayed in Tables 2 and 3.

Both the French and the German auditory targets were produced with the OS X Speech Synthesizer. The naturalness of the synthesized files was checked by two independent native speakers in each language. Auditory files were edited to ensure that any silence at the beginning and end of each item was removed.

Table 2. Psycholinguistic Properties of French and German Nonwords (SDs in Parentheses).

\begin{tabular}{llcll}
\hline Nonwords & Stem+Suffix & Stem+Non-Suffix & Non-stem+Suffix & Non-stem+Non-Suffix \\
& \multicolumn{5}{c}{ French } \\
OLD20 & $2.5(0.6)$ & $2.9(0.5)$ & $2.7(0.6)$ & $3.2(0.6)$ \\
N letters & $8.1(1.3)$ & $8.2(1.1)$ & $8.1(1.3)$ & $8.1(1.2)$ \\
N phonemes & $5.7(1.3)$ & $6.2(1.1)$ & $5.9(1.3)$ & $6.3(1.2)$ \\
& & & German & \\
OLD20 & $2.8(0.6)$ & $2.7(0.5)$ & $3.0(0.7)$ & $2.9(0.5)$ \\
\hline
\end{tabular}

\footnotetext{
${ }^{3}$ It is worth noting that just like suffix frequencies, stem frequencies in the two languages cannot be directly compared, because the size of the corresponding corpora are substantially different.
} 


\begin{tabular}{|c|c|c|c|c|}
\hline $\mathrm{N}$ letters & $7.7(1.2)$ & $7.3(1.2)$ & $7.7(1.2)$ & $7.3(1.2)$ \\
\hline $\mathrm{N}$ phonemes & $6.8(1.1)$ & $6.8(1.1)$ & $6.9(1.1)$ & $6.9(1.1)$ \\
\hline \multicolumn{5}{|c|}{ French vs. German } \\
\hline \multirow[t]{2}{*}{ OLD20 } & $\mathrm{t}(59)=-3.555$ & $\mathrm{t}(59)=2.271$ & $\mathrm{t}(59)=-3.089$, & $\mathrm{t}(59)=3.520$ \\
\hline & $\mathrm{p}=.001$ & $\mathrm{p}=.027$ & $\mathrm{p}=.003$ & $\mathrm{p}=.001$ \\
\hline \multirow[t]{2}{*}{$\mathrm{N}$ letters } & $\mathrm{t}(59)=2.560$ & $\mathrm{t}(59)=4.597$ & $\mathrm{t}(59)=2.560$ & $\mathrm{t}(59)=4.678$ \\
\hline & $\mathrm{p}=.013$ & $\mathrm{p}<.001$ & $\mathrm{p}=.013$ & $\mathrm{p}<.001$ \\
\hline \multirow[t]{2}{*}{ N phonemes } & $\mathrm{t}(59)=-5.169$ & $\mathrm{t}(59)=-3.500$ & $\mathrm{t}(59)=-4.738$, & $\mathrm{t}(59)=-2.929$, \\
\hline & $\mathrm{p}<.001$ & $\mathrm{p}=.001$ & $\mathrm{p}<.001$ & $\mathrm{p}=.005$ \\
\hline \multicolumn{5}{|c|}{ Words and Stems of Nonwords (SDs in Parentheses). } \\
\hline Words & Suffixed Word & Non-Suffix & ed Words & Stems of Nonwords \\
\hline \multicolumn{5}{|c|}{ French } \\
\hline OLD20 & $2.3(0.5)$ & $2.0(0.5)$ & & $1.5(0.4)$ \\
\hline $\mathrm{N}$ letters & $8.1(1.2)$ & $6.7(0.8)$ & & $4.6(1.0)$ \\
\hline $\mathrm{N}$ phonemes & $6.4(1.4)$ & $5.0(0.9)$ & & $3.2(1.0)$ \\
\hline Frequency & $4.0(0.6)$ & $3.7(0.6)$ & & $4.4(0.9)$ \\
\hline \multicolumn{5}{|c|}{ German } \\
\hline OLD20 & $2.3(0.5)$ & $2.3(0.4)$ & & $1.4(0.4)$ \\
\hline $\mathrm{N}$ letters & $7.7(1.2)$ & $6.7(0.8)$ & & $4.3(1.0)$ \\
\hline $\mathrm{N}$ phonemes & $6.3(1.1)$ & $6.2(1.3)$ & & $4.0(0.9)$ \\
\hline Frequency & $4.1(0.5)$ & $3.8(0.6)$ & & $4.7(0.6)$ \\
\hline
\end{tabular}


Procedure. A total of three hundred items (60 words and 240 nonwords) in each language were used in the study. The nonword items belonged to four conditions: Stem + Suffix, Stem + Non-Suffix, Non-Stem + Suffix, Non-Stem + Non-Suffix. The word items belonged to two conditions: Suffixed and Non-Suffixed. Four lists were created with each target word appearing once in every list and each target nonword appearing once across the four lists. Thus, each list comprised 120 items, 60 nonwords ( 15 with stem + suffix, 15 with stem + non-suffix, 15 with non-stem + suffix, and 15 with non-stem + non-suffix) and 60 words (30 suffixed and 30 non-suffixed). Hence, all conditions were represented in each list. An equal number of participants were assigned to each list. The word and nonword items were presented intermixed. The order of trial presentation within each list was randomized across participants. Six practice items consisting of both words and nonwords were presented to the participants prior to the experimental trials.

Participants were tested individually, seated approximately $60 \mathrm{~cm}$ in front of a laptop or a PC monitor in a quiet room. Stimulus presentation and reaction time latencies were controlled by DMDX software (Forster \& Forster, 2003). In the visual lexical decision task, participants were told that words and nonwords would appear on the screen one at a time. Participants were then instructed to press " $\mathrm{K}$ " if the letter string was a word and " $\mathrm{D}$ " if the letter string was a nonword. Items were presented in lowercase letters. However, the first letter of the German items was uppercase, because the first letter of noun forms in German is always written in uppercase. Thus, for consistency, all German items were presented in the same format. Stimuli appeared in white on a black background (20-point Arial font) and remained on the screen for $3000 \mathrm{~ms}$ or until participants responded, whichever happened first. In the auditory lexical decision task, participants wore headphones and were told that they would hear a word or a nonword one at a 
time. Participants had to press the same buttons as for the visual lexical decision task to indicate whether the item they heard was a word or a nonword. A black cross appeared on a white background while the item was presented aurally, and remained on the screen for $3000 \mathrm{~ms}$ or until participants responded, whichever happened first. Reaction times were recorded from stimulus onset. In both tasks, participants were asked to respond as quickly and as accurately as possible.

\section{Analyses}

Analyses were performed using (generalized) linear mixed-effects models (Baayen, Davidson, \& Bates, 2008) as implemented in the lme4 package (Version 1.1-20; Bates, Maechler, Bolker, \& Walker, 2015) in the statistical software R (Version 3.5.1, 2018-07-02, "Feather Spray", RCoreTeam, 2018). RTs were log transformed to normalize residuals and were then analyzed using a linear mixed-effects (LME) model. For the error analysis, a generalized linear mixed-effects (GLME) model was created using logit transformation and a binomial link function. The significance of the fixed effects was determined with type III model comparisons using the Anova function in the car package (Fox \& Weisberg, 2011). Post hoc comparisons were carried out using cell means coding and single $d f$ contrasts with the $g l h t$ function of the multcomp package (Hothorn, Bretz, \& Westfall, 2008) using the normal distribution to evaluate significance.

The data from both languages and tasks were analyzed together. Given that nonwords were the focus of interest in the present study, we only report the nonword analyses. First we report the RT analyses and then the accuracy analyses. The results from the mixed-effects analyses are provided in Table 4 and the mean model RTs and error rates are displayed in Figures 1 and 2. 
Table 4. Summary of Linear Mixed-Effects Analyses for Nonword RTs and Accuracy.

\begin{tabular}{|c|c|c|c|c|}
\hline \multirow[t]{2}{*}{ Variables } & \multicolumn{2}{|l|}{ RTs } & \multicolumn{2}{|c|}{ Accuracy } \\
\hline & $\chi^{2}$ & $p$ & $\chi^{2}$ & $p$ \\
\hline \multicolumn{5}{|l|}{ Fixed effects $(d f)$} \\
\hline Intercept (1) & 287390.000 & $<.001$ & 950.155 & $<.001$ \\
\hline Language (1) & 47.243 & $<.001$ & 1.688 & $=.194$ \\
\hline Stem (1) & 116.610 & $<.001$ & 79.790 & $<.001$ \\
\hline Suffix (1) & 21.028 & $<.001$ & 59.600 & $<.001$ \\
\hline Modality (1) & 6099.800 & $<.001$ & 0.635 & $=.426$ \\
\hline Stem:Suffix (1) & 24.379 & $<.001$ & 1.130 & $=.288$ \\
\hline Stem:Modality (1) & 32.021 & $<.001$ & 8.279 & $=.004$ \\
\hline Suffix:Modality (1) & 111.290 & $<.001$ & 0.811 & $=.368$ \\
\hline Language:Stem (1) & 6.317 & $=.012$ & 1.389 & $=.239$ \\
\hline Language:Suffix (1) & 3.592 & $=.058$ & 1.851 & $=.174$ \\
\hline Language:Modality (1) & 112.770 & $<.001$ & 0.041 & $=.840$ \\
\hline Language:Stem:Suffix (1) & 2.243 & $=.134$ & 0.168 & $=.682$ \\
\hline Language:Stem:Modality (1) & 11.006 & $=.001$ & 4.714 & $=.030$ \\
\hline Language:Suffix:Modality (1) & 0.178 & $=.673$ & 0.288 & $=.591$ \\
\hline Stem:Suffix:Modality (1) & 12.184 & $<.001$ & 2.676 & $=.102$ \\
\hline $\begin{array}{l}\text { Language:Stem:Suffix:Modality } \\
\text { (1) }\end{array}$ & 0.001 & $=.977$ & 3.947 & $=.047$ \\
\hline Order & 155.580 & $<.001$ & & \\
\hline OLD20 & 26.390 & $<.001$ & 40.827 & $<.001$ \\
\hline Letter Length & 56.361 & $<.001$ & 22.706 & $<.001$ \\
\hline Phoneme Length & 36.216 & $<.001$ & 2.141 & $=.143$ \\
\hline
\end{tabular}

\section{Results}

\section{Reaction Times}

Incorrect responses to nonwords (7.1\% of the data) were first removed. Any latencies below 200 or above $2000 \mathrm{~ms}$ (1.3\% of the data) were considered as extreme values and were also removed. Outliers were subsequently removed following the procedure outlined by Baayen and 
Milin (2010). In particular, a base model, which included only participants and items as random intercepts, was fitted to the data and data points with residuals exceeding $2.5 S D$ s were removed ( $0.7 \%$ of the data). The LME model included the effect-coded fixed effects of Language (French vs. German), Stem (Stem vs. Non-Stem), Suffix (Suffix vs. Non-Suffix), and Modality (Auditory vs. Visual), as well as their interaction. Trial Order, OLD20, Letter Length, and Phoneme Length (all standardized) were included in the model as covariates. Random intercepts and random slopes for the effects of Stem and Suffix, and their interaction, were used for both subjects and items.

\section{Stem and suffix effects}

The main effect of Stem was significant. Nonwords with stems $(M=922 \mathrm{~ms}, S E=12)$ were responded to significantly slower $(\Delta=-62 \mathrm{~ms}, z=10.800, p<.001)$ than nonwords without stems $(M=861 \mathrm{~ms}, S E=11)$. Also, the main effect of Suffix was significant. Nonwords with suffixes $(M=904 \mathrm{~ms}, S E=12)$ were responded to significantly slower $(\Delta=-26 \mathrm{~ms}, z=4.586, p$ $<.001)$ than nonwords without suffixes $(M=878 \mathrm{~ms}, S E=11)$. Moreover, the Stem by Suffix interaction was significant. The stem effect for suffixed nonwords $(\Delta=-89 \mathrm{~ms}, z=10.890, p$ $<.001$ ) was substantially larger than the stem effect for non-suffixed nonwords $(\Delta=-35 \mathrm{~ms}, z=$ $4.781, p<.001)$.

\section{Modality effects}

The main effect of Modality was significant. Nonwords in the auditory lexical decision task $(M=1038 \mathrm{~ms}, S E=13)$ were responded to significantly slower $(\Delta=-273 \mathrm{~ms}, z=78.100, p$ $<.001)$ than nonwords in the visual lexical decision task $(M=765 \mathrm{~ms}, S E=10)$. Furthermore, the interaction between Stem and Modality was significant. The stem effect in visual lexical decision $(\Delta=70 \mathrm{~ms}, z=-12.150, p<.001)$ was larger than the stem effect in auditory lexical decision $(\Delta=$ 
$49 \mathrm{~ms}, z=-6.273, p<.001)$. Also, the interaction between Suffix and Modality was significant. The suffix effect was significant in visual lexical decision $(\Delta=54 \mathrm{~ms}, z=-9.390, p<.001)$, but not in auditory lexical decision $(\Delta=-12 \mathrm{~ms}, z=1.575, \mathrm{p}=.115)$. Accordingly, the triple Stem by Suffix by Modality interaction was significant. This was because the stem effect was much larger for suffixed nonwords than for non-suffixed nonwords in the visual lexical decision task $(z=$ $6.035, p<.001)$, compared to the auditory lexical decision task $(z=2.188, p=0.029)$.

\section{Language effects}

The main effect of Language was significant. French participants $(M=974 \mathrm{~ms}, S E=18)$ were significantly slower $(\Delta=-158 \mathrm{~ms}, z=6.873, p<.001)$ than German participants $(M=815$ $\mathrm{ms}, S E=15)$. Critically for the hypotheses tested in the present study, the Language by Stem interaction was significant. The stem effect in German $(\Delta=69 \mathrm{~ms}, z=9.580, p<.001)$ was much larger than the stem effect in French $(\Delta=52 \mathrm{~ms}, z=5.925, p<.001)$. Even though the Language by Suffix interaction only approached significance, post-hoc contrasts revealed that the suffix effect in German $(\Delta=34 \mathrm{~ms}, z=4.801, p<.001)$ was larger than the suffix effect in French $(\Delta=$ $17 \mathrm{~ms}, z=1.885, p=.060$ ). In addition, the interaction between Language and Modality was significant. Differences between the visual and aural tasks in German $(\Delta=284 \mathrm{~ms}, z=-63.580, p$ $<.001)$ were much larger than differences between the two types of tasks in French $(\Delta=258 \mathrm{~ms}$, $z=-47.100, p<.001)$. As per our predictions, the interaction between Language, Stem, and Modality were significant. Post-hoc contrasts showed that the stem effect was not modulated by type of task in French $(z=1.635, p=0.102)$, but it was significantly bigger in visual than in auditory lexical decision in German $(z=6.428, p<.001)$.

Taken together, our results show that morphology plays an important role both visually and aurally. However, morphological influences seem to be more robust in the visual than in the 
auditory domain. In addition, morphological processing seems to be more robust in German than in French. Also, compared to French, the observed morphological effects in German are much more prominent in the visual than in the auditory modality.

Figure 1. Lexical Decision Latencies (in Milliseconds) and Standard Errors for Nonwords in Visual and Auditory LDT.
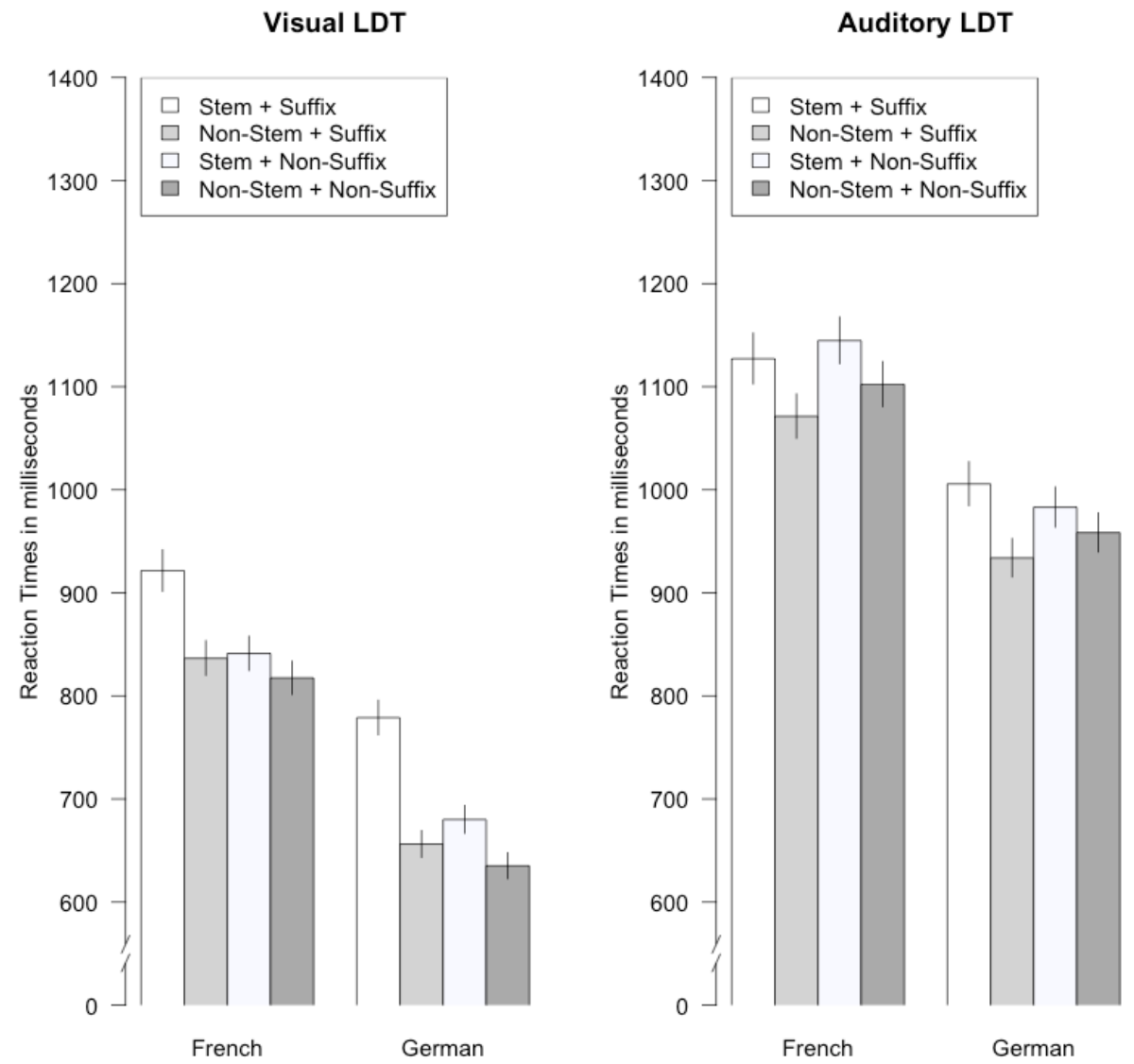

Accuracy

The error analyses were conducted in the same way as for RTs. The GLME model included the same fixed effects and interactions as the LME model, . OLD20, Letter Length, and Phoneme Length (all standardized) were included in the model as covariates. 


\section{Stem and suffix effects}

The main effect of Stem was significant. Nonwords with stems $(M=5.0, S E=0.5)$ yielded more errors $(\Delta=3.3, z=-7.608, p<.001)$ than nonwords without stems $(M=1.7, S E=$ 0.2). Also, the main effect of Suffix was significant. Nonwords with suffixes $(M=5.4, S E=0.6)$ yielded more errors $(\Delta=3.8, z=-7.844, p<.001)$ than nonwords without suffixes $(M=1.6, S E=$ $0.2)$.

\section{Modality effects}

The interaction between Stem and Modality was significant. Nonwords with stems yielded more errors in the visual lexical decision task $(\Delta=4.3, z=7.505, p<.001)$ than in the auditory lexical decision task $(\Delta=2.4, z=4.349, p<.001)$.

\section{Language effects}

The interaction between Language, Stem, and Modality was significant. Post-hoc contrasts showed that the stem effect was not modulated by type of task in French $(z=-0.598, p$ $=.550)$, but it was significantly bigger in visual than in auditory lexical decision in German $(z=-$ $3.247, p=.001)$. In addition, the interaction between Language, Stem, Suffix, and Modality was significant. This was because the stem effect for nonwords with and without suffixes was similar across modalities in French $(z=-0.302, p=.763)$, but it was much bigger in the visual than in the auditory modality in German $(z=2.353, p=.019)$.

Taken together, the results from the analyses on nonword accuracy showed that morphological effects in German are more prominent in the visual than in the auditory modality. Figure 2. Accuracy (\% Error) and Standard Errors for Nonwords in Visual and Auditory LDT. 

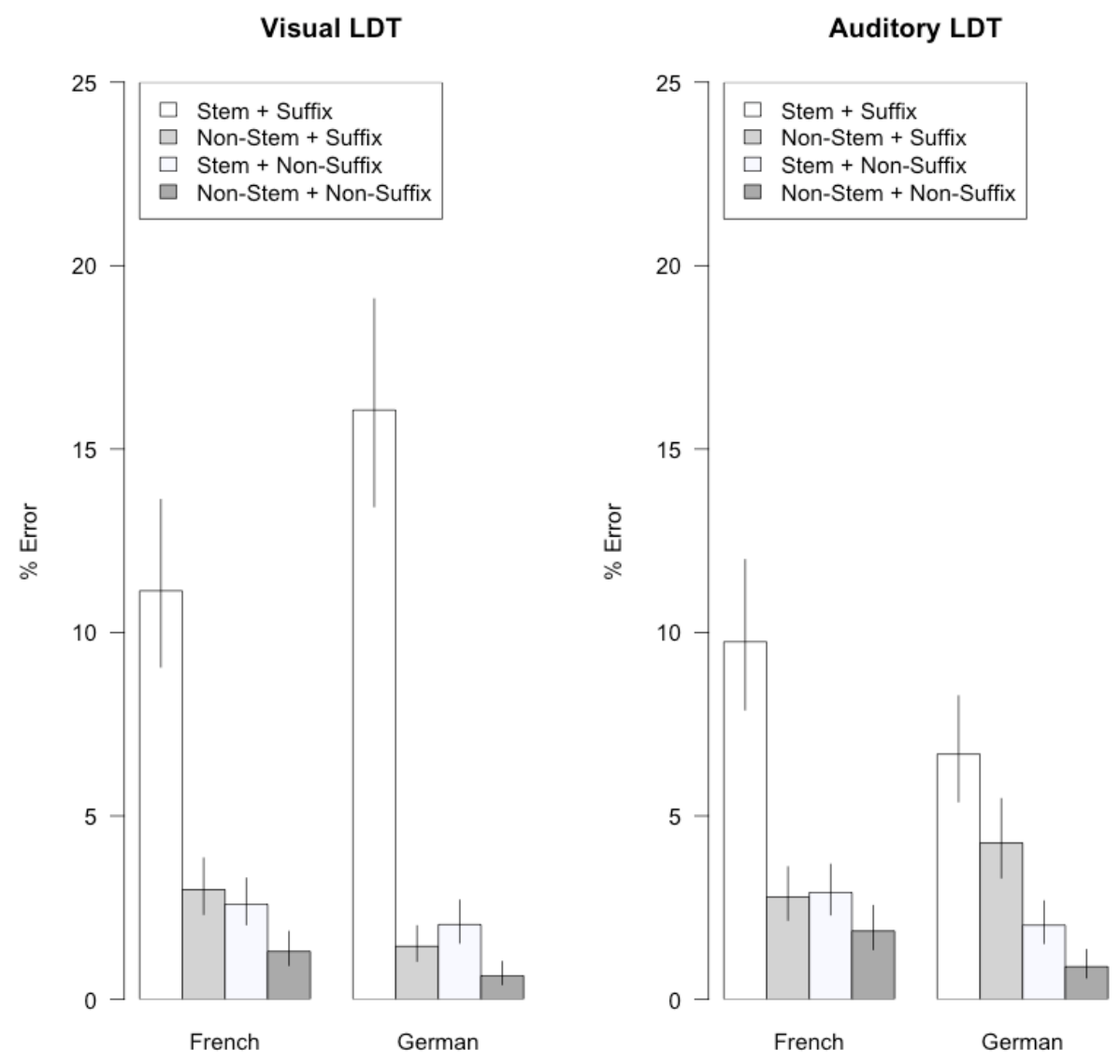

\section{Discussion}

The present study is the first to investigate morphological processing in different modalities (visual vs. auditory) in a cross-linguistic fashion (French vs. German). To study the combined effect of morphemic stems and suffixes, we focused our investigations on four types of morphologically complex nonwords, namely nonwords consisting of a Stem + Suffix, a Stem + Non-Suffix, a Non-Stem + Suffix, and a Non-Stem + Non-Suffix. Our results revealed robust differences between modalities and languages. We summarize these below.

The first goal of our study was to test the hypothesis that morphological processing may be more prominent in the visual than in the aural modality, given that morphology is represented more consistently in written language (e.g., Desrochers et al., 2017; Landerl \& Reitsma, 2005; 
Rastle, 2018). Our data support this hypothesis, showing that morphological structure has a greater impact on processing in the visual than in the auditory modality. This was evidenced by significant Stem-by-Modality and Suffix-by-Modality interactions (see Figures 1 and 2). This is a novel finding, not only because the direct comparison between processing of derivational morphology in the two modalities has not been previously made, but also because our experimental design allowed us to clearly dissociate the role of the stem and the suffix in visual and auditory recognition processes. Our data show that the presence of a stem or a suffix made it more difficult to reject a nonword in a lexical decision task, and that this difficulty was greater in the visual than in the auditory domain. This suggests that in the visual modality, stems and suffixes were more rapidly identified and mapped onto existing morphemic representations than in the auditory modality. Therefore, our data provide support for the hypothesis that morphology plays a more prominent role in visual than in auditory word recognition, presumably because of the greater consistency of morphological units in printed form.

In addition, we investigated whether morphological processing is modulated by languagespecific differences in morphological productivity. On the assumption that German is more morphologically productive than French (e.g., Juola, 2008; Kettunen, 2014; Sadeniemi et al., 2008), we hypothesized that morphological processing effects would also be greater in German than in French. Our results revealed a significant Language-by-Stem interaction, while the Language-by-Suffix interaction approached significance, showing that the influence of morphology - and in particular stem processing - was more robust in German than in French. This finding was further supported by a three-way interaction between Language, Stem, and Modality, which was significant both in terms of response latencies and accuracy (see Figures 1 and 2). The significantly larger stem effect in German compared to French indicates that German 
speakers are more proficient in rapidly extracting embedded stems, and this seems to be particularly robust in the visual domain. Our data thus suggest that the lexical system benefits from repeated exposure to morphological regularities, as it is the case in morphologically productive languages like German. We speculate that the productivity of the compounding system, for which German stands out as being one of the most productive amongst IndoEuropean languages, might be the reason why stem extraction is effortless in this language. ${ }^{4}$

One question that arises from the present findings is whether the identification of stem morphemes and affixes is based on the same core processing mechanisms, or whether the two types of morphemes have an entirely different status in the word recognition system. The first option is that the processing of stems and affixes is governed by the same morphological chunking mechanisms, but that the efficiency of the mechanism is determined by how frequently stems and suffixes are used within a specific language context. This is in line with theories suggesting that morphologically complex words (e.g., farmer) are initially "decomposed" and mapped onto specialized morphemic representations (e.g., the stem farm and the suffix -er), which are then in turn used to generate the combined meaning of the whole word (e.g., Baayen \& Schreuder, 1999; Beyersmann, Coltheart, \& Castles, 2012; Crepaldi, Rastle, Coltheart, \& Nickels, 2010; Diependaele, Sandra, \& Grainger, 2009; Taft, 2003). However, on the assumption

\footnotetext{
${ }^{4}$ It is worth noting that in a recent cross-linguistic study that investigated morphological effects on reading aloud as a function of the orthographic consistency and morphological complexity of a language (Mousikou et al., 2019), we observed that it is the orthographic consistency of a language, rather than its morphological complexity, that influences morphological processing in reading aloud. However, the consistency with which letters in a certain language map onto phonemes is critical for reading aloud, which could explain why this particular language characteristic influenced morphological processing in this task over and above morphological complexity.
} 
that stems and affixes are handled by the same kind of decompositional mechanism and are therefore closely associated, it is more difficult to explain why the observed cross-linguistic differences in the stem effect were more robust than those in the suffix effect.

The alternative option is based on a more recent proposal by Grainger and Beyersmann (2017) who argued that stems and suffixes are processed in different ways. While affixes always occur in combination with a stem morpheme, stems themselves can occur as free-standing lexical units and therefore do not require setting up any specialized morphological representations (see also Beyersmann \& Grainger, 2018). As such, stems can be activated simply by mapping embedded stems onto existing whole-word representations in the lexicon. This idea finds support in recent evidence from masked priming data in the lexical decision task, showing that embedded stems are rapidly activated independently of whether they are accompanied by a suffix or a nonmorphemic ending (e.g., Beyersmann, Casalis, Ziegler, \& Grainger, 2015; Beyersmann, Cavalli, Casalis, \& Colé, 2016; Beyersmann et al., 2018; Hasenäcker, Beyersmann, \& Schroeder, 2016; Heathcote, Nation, Castles, \& Beyersmann, 2018; Morris, Porter, Grainger, \& Holcomb, 2011; Mousikou \& Schroeder, 2019; Taft, Li, \& Beyersmann, 2018). Suffixes on the other hand require a specialized chunking mechanism by which they are identified and removed from the rest input signal. The identification of an affix then sends in turn an activation boost to the embedded stem, which explains why masked priming studies with affixed and pseudo-affixed words (e.g., Longtin et al., 2003; Rastle \& Davis, 2008; Rastle et al., 2004) typically show more priming to their embedded stems (e.g., farmer-farm and corner-corn) than non-affixed control words (e.g., cashew-cash). On the assumption that stems and affixes are handled by two entirely different mechanisms, this theoretical framework is in a better position to explain the presence of a significant Language by Stem interaction (i.e. a bigger stem effect in German than in French) in 
the absence of a significant Language by Suffix interaction. Stem-stem combinations form a central component of the German lexical system due to the productivity of the compounding system. Naturally, repeated exposure to compound words would then lead to the development of an efficient routine procedure to rapidly map embedded stems onto existing representations in the mental lexicon, while leaving the affix-chunking mechanism unaffected. Hence, Grainger and Beyersmann's (2017) theoretical framework provides an explanation for the present findings.

Finally, the results revealed an expected main effect of modality, showing that responses were overall slower in auditory than in visual lexical decision. While the visual system can perform a quick initial form-based analysis of the letter string, the seriality of the spoken input imposes a minimal time for word identification. A key follow-up of the current investigation would therefore be the examination of prefixed nonwords, to test if modality differences are replicable when the seriality of stem and affix is reversed. The main effect of language was also significant, showing that German participants responded overall faster than French participants, and so was the language-by-modality interaction, indicating greater language differences in the visual modality. French has less consistent print-to-sound and sound-to-print mappings than German (Ellis et al., 2004; Seymour, Aro, \& Erskine, 2003). Thus, differences in response latencies between the two samples could be due to the substantial number of silent letters in the French nonwords (compare number of letters to number of phonemes for French in Table 2). The presence of silent letters in the French nonwords would likely increase the uncertainty of printto-sound and sound-to-print mappings in this language, thus slowing down decision times in the French sample. 
In sum, the present data provide a broader cross-modality and cross-linguistic perspective on the mechanisms involved in morphological processing. The greater impact of morphology within the written modality, which we hypothesize is likely due to the greater consistency of morphology in print, suggests that adults clearly benefit from morphological knowledge during reading. Moreover, the observed cross-linguistic differences in morphological processing demonstrate that language-specific characteristics can influence the cognitive mechanisms underlying visual and auditory word recognition. 


\section{Acknowledgements}

This research was supported by grants from the French National Agency for Research (ANR) and the German Research Foundation (DFG), in particular the French-German ANR/DFG grant scheme in social sciences and humanities (ANR-15-FRAL-0003-01) and a DFG grant (SCHR1268/2-1). The research also benefitted from support from grants ANR-16-CONV-0002, ANR11-LABX-0036). EB was supported by a Discovery Early Career Researcher Award (DECRA) by the Australian Research Council (DE190100850), and JG by ERC grant 742141. 


\section{References}

Amenta, S., \& Crepaldi, D. (2012). Morphological processing as we know it: an analytical review of morphological effects in visual word identification. Frontiers in Psychology, 3, 1-12.

Baayen, R. H., Davidson, D. J., \& Bates, D. M. (2008). Mixed-effects modeling with crossed random effects for subjects and items. Journal of Memory and Language, 59, 390-412.

Baayen, R. H., \& Milin, P. (2010). Analyzing reaction times. International Journal of Psychological Research, 3, 12-28.

Baayen, R. H., Piepenbrock, R., \& van Rijn, H. (1993). The CELEX lexical database (CDROM).

Baayen, R. H., \& Schreuder, R. (1999). War and peace: Morphemes and full forms in a noninteractive activation parallel dual-route model. Brain and Language, 68(1-2), 27-32.

Bates, D., Maechler, M., Bolker, B., \& Walker, S. (2015). Fitting Linear Mixed-Effects Models Using lme4. . Journal of Statistical Software, 67, 1-48. doi:http://dx.doi.org/10.18637/jss.v067.i01

Bauer, L. (2001). Morphological productivity. Cambridge: Cambridge University Press.

Berg, K., \& Aronoff, M. (2017). Self-organization in the spelling of English suffixes: The emergence of culture out of anarchy. Language, 93(1), 37-64. doi:10.1353/lan.2017.0000

Berg, K., Buchmann, F., Dybiec, K., \& Fuhrhop, N. (2014). Morphological spellings in English. Written Language and Literacy, 14(2), 282-307.

Beyersmann, E., Bolger, D., Pattamadilok, C., New, B., Ziegler, J. C., \& Grainger, J. (2019). Morphological processing without semantics: An ERP study with spoken words. Cortex, 116, 55-73. 
Beyersmann, E., Casalis, S., Ziegler, J. C., \& Grainger, J. (2015). Language proficiency and morpho-orthographic segmentation. Psychonomic Bulletin \& Review, 22, 1054-1061.

Beyersmann, E., Cavalli, E., Casalis, S., \& Colé, P. (2016). Embedded Stem Priming Effects in Prefixed and Suffixed Pseudowords. Scientific Studies of Reading, 20(3), 220-230. doi:10.1080/10888438.2016.1140769

Beyersmann, E., Coltheart, M., \& Castles, A. (2012). Parallel processing of whole-words and morphemes in visual word recognition. The Quarterly Journal of Experimental Psychology, 65(9), 1798-1819.

Beyersmann, E., \& Grainger, J. (2018). Support from the morphological family when unembedding the stem. Journal of Experimental Psychology: Learning, Memory and Cognition, 44(1), 135-142.

Beyersmann, E., Kezilas, Y., Coltheart, M., Castles, A., Ziegler, J. C., Taft, M., \& Grainger, J. (2018). Taking the book from the bookshelf: Masked constituent priming effects in compound words and nonwords. Journal of Cognition, 1(1), 1-10.

Beyersmann, E., Wegener, S., Nation, K., Prokupzcuk, A., Wang, H.-C., \& Castles, A. (in press). Learning morphologically complex spoken words: Orthographic expectations of embedded stems are formed prior to print exposure. Journal of Experimental Psychology: Learning, Memory and Cognition.

Beyersmann, E., Ziegler, J. C., Castles, A., Coltheart, M., Kezilas, Y., \& Grainger, J. (2016). Morpho-orthographic segmentation without semantics. Psychonomic Bulletin \& Review, 23, 533-539. doi:10.3758/s13423-015-0927-z

Borleffs, E., Maassen, B. A. M., Lyytinen, H., \& Zwarts, F. (2017). Measuring orthographic transparency and morphological-syllabic complexity in alphabetic orthographies: a 
narrative review. Reading and Writing, 30(8), 1617-1638. doi:10.1007/s11145-017-97415

Brysbaert, M., Buchmeier, M., Conrad, M., Jacobs, A. M., Bölte, J., \& Böhl, A. (2011). The word frequency effect: A review of recent developments and implications for the choice of frequency estimates in German. Experimental Psychology, 58, 412-424.

Carney, E. (1994). A survey of English spelling. London: Routledge.

Crepaldi, D., Rastle, K., Coltheart, M., \& Nickels, L. (2010). 'Fell' primes 'fall', but does 'bell' prime 'ball'? Masked priming with irregularly-inflected primes. Journal of Memory \& Language, 63, 83-99.

Creutz, M., \& Lagus, K. (2005). Unsupervised morpheme segmentation and morphology induction from text corpora Technical Report No. A81. Helsinki University of Technology, Espoo: Laboratory of Computer and Information Science.

Creutz, M., Lagus, K., Lindén, K., \& Virpioja, S. (2005). Morfessor and hutmegs: Unsupervised morpheme segmentation for highly-inflecting and compounding languages. Paper presented at the Proceedings of the 2nd Baltic Conference on Human Language Technologies, Tallinn.

Dawson, N., Rastle, K., \& Ricketts, J. (2018). Morphological effects in visual word recognition: Children, adolecents, and adults. Journal of Experimental Psychology: Learning, Memory and Cognition, 44(4), 645-654. doi:10.1037/xlm0000485

Desrochers, A., Manolitsis, G., Gaudreau, P., \& Georgiou, G. (2017). Early contribution of morphological awareness to literacy skills across languages varying in orthographic consistency. Reading and Writing, 31(8), 1695-1719. doi:10.1007/s11145-017-9772-y 
Diependaele, K., Sandra, D., \& Grainger, J. (2009). Semantic transparency and masked morphological priming: The case of prefixed words. Memory \& Cognition, 37, 895-908.

Ellis, N. C., Natsume, M., Stavropoulou, K., Hoxhallari, L., Daal, V. H. P., Polyzoe, N., . . Petalas, M. (2004). The effects of orthographic depth on learning to read alphabetic, syllabic, and logographic scripts. Reading Research Quarterly, 39(4), 438-468. doi:10.1598/rrq.39.4.5

Fleischer, W., \& Barz, I. (1995). Wortbildung der deutschen Gegenwartssprache. Tübingen: Niemeyer.

Forster, K. I., \& Forster, J. C. (2003). DMDX: A Windows display program with millisecond accuracy. Behavior Research Methods, Instruments, \& Computers, 35(1), 116-124.

Fox, J., \& Weisberg, S. (2011). An R companion to applied regression (2nd ed.) CA: Thousand Oaks.

Frost, R., \& Ziegler, J. C. (2007). Speech and Spelling Interaction: The Interdependence of Visual and Auditory Word Recognition. In M. G. Gaskell (Ed.), The Oxford Handbook of Psycholinguistics (pp. 107-118). Oxford: Oxford University Press.

Fuhrhop, N. (2011). Grammatik verstehen lernen - Grammatik sehen lernen. In K. M. Köpcke \& A. Ziegler (Eds.), Grammatik - Lehren, Lernen, Verstehen: Zugänge zur Grammatik des Gegenwartsdeutschen (pp. 307-324). Berlin: De Gruyter.

Grainger, J., \& Beyersmann, E. (2017). Edge-aligned embedded word activation initiates morpho-orthographic segmentation. In B. H. Ross (Ed.), The Psychology of Learning and Motivation (Vol. 67, pp. 285-317). San Diego, CA: Academic Press. 
Grainger, J., \& Holcomb, P. J. (2009). Watching the word go by: On the time-course of component processes in visual word recognition. Language and Linguistics Compass, 3, 128-156.

Grainger, J., \& Ziegler, J. C. (2008). Cross-code consistency in a functional architecture for word recognition. In E. L. Grigorenko \& A. Naples (Eds.), Single-word reading: Biological and behavioral perspectives (pp. 129-157). Mahwah, NJ: Lawrence Erlbaum Associates.

Hasenäcker, J., Beyersmann, E., \& Schroeder, S. (2016). Masked morphological priming in German-speaking adults and children: Evidence from response time distributions. Frontiers in Psychology, 7, 1-11. doi:10.3389/fpsyg.2016.00929

Hay, J. B., \& Baayen, R. H. (2002). Parsing and productivity. In G. E. Booij \& J. van Marle (Eds.), Yearbook of Morphology 2001. Dordrecht: Kluwer Academic Publishers.

Heathcote, L., Nation, K., Castles, A., \& Beyersmann, E. (2018). Do 'blacheap' and 'subcheap' both prime 'cheap'? An investigation of morphemic status and position in early visual word processing. Quarterly Journal of Experimental Psychology, 71(8), 1645-1654.

Hothorn, T., Bretz, F., \& Westfall, P. (2008). Simultaneous inference in general parametric models. Biometrical Journal: Biometrische Zeitschrift, 50, 346-363.

Inhoff, A. W., Radach, R., \& Heller, D. (2000). Complex Compounds in German: Interword Spaces Facilitate Segmentation but Hinder Assignment of Meaning. Journal of Memory and Language, 42(1), 23-50. doi:10.1006/jmla.1999.2666

Johnston, M. B., McKague, M., \& Pratt, C. (2004). Evidence for an automatic code in the processing of visually novel word forms. Language and Cognitive Processes, 19, 273317. 
Juola, P. (1998). Measuring linguistic complexity: The morphological tier. Journal of Quantitative Linguistics, 5, 206-213. doi:https://doi.org/10.1080/09296179808590128

Juola, P. (2008). Assessing linguistic complexity. In M. Miestamo, K. Sinnemäki, \& F. Karlsson (Eds.), Language complexity: Typology, contact, change (pp. 89-108). Amsterdam: John Benjamins Publishing Company.

Kettunen, K. (2014). Can Type-Token Ratio be Used to Show Morphological Complexity of Languages? Journal of Quantitative Linguistics, 21(3), 223-245. doi:10.1080/09296174.2014.911506

Kuo, L.-J., \& Anderson, R. C. (2006). Morphological awareness and learning to read: A crosslinguistic perspective. Educational Psychologist, 41(3), 161-180.

Landerl, K., \& Reitsma, P. (2005). Phonological and morphological consistency in the acquisition of vowel duration spelling in Dutch and German. Journal of Experimental Child Psychology, 92(4), 322-344. doi:10.1016/j.jecp.2005.04.005

Lavric, A., Elchlepp, H., \& Rastle, K. (2012). Tracking hierarchical processing in morphological decomposition with brain potentials. Journal of Experimental Psychology: Human Perception and Performance, 38(4), 811-816.

Leinonen, A., Gronholm-Nyman, P., Jarvenpaa, M., Soderholm, C., Lappi, O., Laine, M., \& Krause, C. M. (2009). Neurocognitive processing of auditorily and visually presented inflected words and pseudowords: evidence from a morphologically rich language. Brain Research, 1275, 54-66. doi:10.1016/j.brainres.2009.03.057

Longtin, C. M., Segui, J., \& Hallé, P. A. (2003). Morphological priming without morphological relationship. Language and Cognitive Processes, 18(3), 313-334. 
Marslen-Wilson, W., Tyler, L., Waksler, R., \& Older, L. (1994). Morphology and Meaning in the English Mental Lexicon. Psychological Review, 101, 3-33.

McKague, M., Davis, C., Pratt, C., \& Johnston, M. B. (2008). The role of feedback from phonology to orthography in orthographic learning: An extension of item-based accounts. Journal of Research in Reading, 31, 55-76.

Meunier, F., \& Longtin, C. M. (2007). Morphological decomposition and semantic integration in word processing. Journal of Memory and Language, 56, 457-471.

Meyer, R. (1993). Compound comprehension in isolation and in context: The contribution of conceptual and discourse knowledge to the comprehension of German novel noun-noun compounds. Tübingen: Niemeyer.

Morris, J., Porter, J. H., Grainger, J., \& Holcomb, P. J. (2011). Effects of lexical status and morphological complexity in masked priming: An ERP study. Language and Cognitive Processes, 26(4-6), 558-599.

Mousikou, P., Beyersmann, E., Ktori, M., Javourey, L., Crepaldi, D., Ziegler, J. C., ... S., S. (2019). Orthographic consistency influences morphological processing in reading aloud: Evidence from a cross-linguistic study. Manuscript submitted for publication.

Mousikou, P., \& Schroeder, S. (2019). Morphological processing in single-word and sentence reading. Journal of Experimental Psychology: Learning, Memory, and Cognition, 45, 881-903.

New, B., Pallier, C., Brysbaert, M., \& Ferrand, L. (2004). Lexique 2: A new French lexical database. Behavior Research Methods, Instruments, \& Computers, 36, 516-524.

Nicoladis, E. (2001). When is a preposition a linking element? Bilingual children's acquisition o French comound nouns. Folia Linguistica, 36, 45-63. 
Nicoladis, E., \& Krott, A. (2007). Word family size and French-speaking children's segmentation of existing compounds. Language Learning, 57(2), 201-228.

Peereman, R., Sprenger-Charolles, L., \& Messaoud-Galusi, S. (2013). The contribution of morphology to the consistency of spelling-to-sound relations: A quatitative analysis based on French elementary school readers. L'Année Psychologique, 1, 3-33.

Perre, L., Midgley, K., \& Ziegler, J. C. (2009). When beef primes reef more than leaf: Orthographic information affects phonological priming in spoken word recognition. Psychophysiology, 46(4), 739-746.

Pollatsek, A., \& Treiman, R. (2015). Oxford Handbook of Reading. Cary, USA: Oxford University Press.

Rastle, K. (2018). The place of morphology in learning to read in English. Cortex. doi:https://doi.org/10.1016/j.cortex.2018.02.008

Rastle, K., \& Davis, M. H. (2008). Morphological decomposition based on the analysis of orthography. Language \& Cognitive Processes, 23, 942-971.

Rastle, K., Davis, M. H., \& New, B. (2004). The broth in my brother's brothel: Morphoorthographic segmentation in visual word recognition. Psychonomic Bulletin \& Review, $11,1090-1098$.

RCoreTeam. (2018). R: A language and environment for statistical computing. R Foundation for Statistical Computing, Vienna, Austria. Retrieved from https://www.R-project.org/

Sadeniemi, M., Kettunen, K., Lindh-Knuutila, T., \& Honkela, T. (2008). Complexity of European Union Languages: A comparative approach. Journal of Quantitative Linguistics, 15(2), 185-211. doi:10.1080/09296170801961843 
Seymour, P. H. K., Aro, M., \& Erskine, J. M. (2003). Foundation literacy acquisition in European orthographies. British Journal of Psychology, 94, 143-174.

Taft, M. (2003). Morphological representation as a correlation between form and meaning. In E. Assink \& D. Sandra (Eds.), Reading complex words (pp. 113-137). Amsterdam: Kluwer. Taft, M., \& Forster, K. I. (1975). Lexical storage and retrieval of prefixed words. Journal of Verbal Learning and Verbal Behavior, 14, 638-647.

Taft, M., Li, S., \& Beyersmann, E. (2018). What cross-morphemic letter transposition in derived nonwords tells us about lexical processing. Journal of Cognition, 1(1). doi:10.5334/joc.39

Treiman, R., \& Bourassa, D. C. (2000). The development of spelling skill. Topics in Language Disorders, 20(3), 1-18.

Ulicheva, A., Harvey, H., Aronoff, M., \& Rastle, K. (2018). Skilled readers' sensitivity to meaningful regularities in English writing. Cognition. doi:10.1016/j.cognition.2018.09.013

Vannest, J., Newport, E. L., Newman, A. J., \& Bavelier, D. (2011). Interplay between morphology and frequency in lexical access: the case of the base frequency effect. Brain Research, 1373, 144-159. doi:10.1016/j.brainres.2010.12.022

Wegener, S., Wang, H. C., de Lissa, P., Robidoux, S., Nation, K., \& Castles, A. (2018). Children reading spoken words: interactions between vocabulary and orthographic expectancy. Developmental Science, 21(3), 1-9. doi:10.1111/desc.12577

Winsler, K., Midgley, K., Grainger, J., \& Holcomb, P. J. (2018). An electrophysiological megastudy of spoken word recognition. Language, Cognition and Neuroscience, 33(8), 1063-1082. 
Wurm, L. (1997). Auditory Processing of Prefixed English Words Is Both Continuous and Decompositional. Journal of Memory \& Language, 37, 438-461.

Wurm, L. (2000). Auditory processing of polymorphemic pseudowords. Journal of Memory and Language, 42, 255-271.

Wurm, L., \& Ross, S. E. (2001). Conditional root uniqueness points: Psychological validity and perceptual consequences. Journal of Memory and Language, 45(1), 39-57. doi:10.1006/jmla.2000.2758

Yarkoni, T., Balota, D., \& Yap, M. (2008). Moving beyond Coltheart's N: A new measure of orthographic similarity. Psychonomic Bulletin \& Review, 15(5), 971-979.

Zweig, E., \& Pylkkänen, L. (2009). A visual M170 effect of morphological complexity. Language and Cognitive Processes, 24(3), 412-439. doi:10.1080/01690960802180420 
Appendix. Items used in the study.

Nonwords

Stem+Suffix

Stem+Non-Suffix

\begin{tabular}{|c|c|c|c|}
\hline French & German & French & German \\
\hline brasable & Armbar & brasaste & Armucht \\
\hline arbrement & Baumkeit & arbrelot & Baumarf \\
\hline jambeable & Beinbar & jambelot & Beinatz \\
\hline balaiment & Besenkeit & balailot & Besenau \\
\hline liteur & Better & literge & Bettarf \\
\hline foudrement & Blitzkeit & foudrenule & Blitzpern \\
\hline sangeux & Bluthaft & sangonne & Blutam \\
\hline lettrement & Briefkeit & lettrenule & Briefmen \\
\hline paineux & Brothaft & painache & Brotarf \\
\hline seineur & Bruster & seinate & Brustekt \\
\hline busion & Busung & busuque & Busarf \\
\hline toiteur & Dacher & toitipe & Dachpfen \\
\hline glacable & Eisbar & glacenule & Eismen \\
\hline champeux & Feldbar & champonne & Feldatz \\
\hline filmeux & Filmhaft & filmuque & Filmarf \\
\hline volment & Flugkeit & volige & Flugucht \\
\hline halleux & Flurbar & hallache & Flurpern \\
\hline facement & Gesichtkeit & facenure & Gesichtarf \\
\hline fantômement & Gespenstkeit & fantômenule & Gespenstpern \\
\hline arrêtment & Haltkeit & arrêtipe & Haltarf \\
\hline boision & Holzung & boisipe & Holzat \\
\hline pouletable & Huhnbar & pouletème & Huhnam \\
\hline chienion & Hundung & chienaste & Hundat \\
\hline biscuitable & Keksbar & biscuitil & Keksmen \\
\hline garsable & Kerlbar & garsare & Kerlmen \\
\hline têtement & Kopfkeit & têtelot & Kopfekt \\
\hline troument & Lochkeit & trounure & Lochucht \\
\hline airement & Luftkeit & airenure & Luftucht \\
\hline sourisment & Mauskeit & sourisisse & Mauspern \\
\hline laitment & Milchkeit & laitope & Milcharf \\
\hline lunement & Mondkeit & lunelot & Mondatz \\
\hline nuiteur & Nachter & nuiterge & Nachtatz \\
\hline nidion & Nestung & nidil & Nestarf \\
\hline parcable & Parkbar & parcache & Parkarf \\
\hline chevalion & Pferdung & chevalème & Pferdam \\
\hline pointment & Punktkeit & pointerge & Punktam \\
\hline rouement & Radkeit & rouenure & Radam \\
\hline droiteux & Rechtbar & droitate & Rechtmen \\
\hline
\end{tabular}




\begin{tabular}{|c|c|c|c|}
\hline jusion & Saftung & jusache & Saftmen \\
\hline sablion & Sandung & sablenule & Sanducht \\
\hline trésorion & Schatzung & trésorisse & Schatzarf \\
\hline sension & Sinnung & sensare & Sinnau \\
\hline pistement & Spurkeit & pistenure & Spurnauf \\
\hline pierrement & Steinung & pierrenule & Steinam \\
\hline fronteux & Stirnbar & frontaste & Stirnatz \\
\hline jourable & Tagbar & jourouse & Tagucht \\
\hline tapisable & Teppichbar & tapisisse & Teppichatz \\
\hline tablement & Tischkeit & tablenure & Tischarf \\
\hline poteux & Topfbar & potare & Topfekt \\
\hline tunnelion & Tunnelung & tunnelipe & Tunnelau \\
\hline mureux & Wandbar & muruque & Wandekt \\
\hline mondement & Weltkeit & mondenure & Weltekt \\
\hline ventable & Windbar & venterge & Winducht \\
\hline blaguement & Witzkeit & blaguipe & Witzarf \\
\hline loupeux & Wolfhaft & loupouse & Wolfat \\
\hline motieux & Worthaft & motige & Wortpern \\
\hline denteur & Zahner & dentaste & Zahnarf \\
\hline tempsable & Zeitbar & tempsouse & Zeitam \\
\hline tentement & Zeltkeit & tentenure & Zeltat \\
\hline traineux & Zughaft & trainaste & Zugat \\
\hline Non-Stem+Suffix & \multicolumn{3}{|c|}{ Non-Stem+Non-Suffix } \\
\hline French & German & French & German \\
\hline brusable & Arfbar & brusast & Arfucht \\
\hline aubrement & Baufkeit & aubrelot & Baufarf \\
\hline jombeable & Beunbar & jombelot & Beunatz \\
\hline bavaiment & Belenkeit & bavailot & Belenau \\
\hline lateur & Botter & laterge & Bottarf \\
\hline foidrement & Blatzkeit & foidrenule & Blatzpern \\
\hline sargeux & Blethaft & sargonne & Bletam \\
\hline lottrement & Bliefkeit & lottrenule & Bliefmen \\
\hline paimeux & Bromhaft & paimache & Bromarf \\
\hline seifeur & Bluster & seifate & Blustekt \\
\hline bumion & Bumung & bumuque & Bumarf \\
\hline taiteur & Ducher & taitipe & Duchpfen \\
\hline glatable & Eusbar & glatenule & Eusmen \\
\hline chalpeux & Faldbar & chalponne & Faldatz \\
\hline falmeux & Filthaft & falmuque & Filtarf \\
\hline vosment & Fluskeit & vosige & Flusucht \\
\hline holleux & Flerbar & hollache & Flerpern \\
\hline ficement & Gosichtkeit & ficenure & Gosichtarf \\
\hline fastômement & Gestenstkeit & fastômenule & Gestenstpern \\
\hline arvêtment & Holtkeit & arvêtipe & Holtarf \\
\hline
\end{tabular}




\begin{tabular}{|c|c|c|c|}
\hline boimion & Holmung & boimipe & Holmat \\
\hline pauletable & Hehnbar & pauletème & Hehnam \\
\hline chionion & Hondung & chionaste & Hondat \\
\hline bisfuitable & Kelsbar & bisfuitil & Kelsmen \\
\hline garpable & Kertbar & garpare & Kertmen \\
\hline têrement & Korfkeit & têrelot & Korfekt \\
\hline traument & Lechkeit & traunure & Lechucht \\
\hline aipement & Luptkeit & aipenure & Luptucht \\
\hline sourifment & Maunkeit & sourifisse & Maunpern \\
\hline lautment & Mulchkeit & lautope & Mulcharf \\
\hline luvement & Moldkeit & luvelot & Moldatz \\
\hline naiteur & Nechter & naiterge & Nechtatz \\
\hline nedion & Nostung & nedil & Nostarf \\
\hline parmable & Parmbar & parmache & Parmarf \\
\hline chetalion & Pfeldung & chetalème & Pfeldam \\
\hline poiltment & Pulktkeit & poilterge & Pulktam \\
\hline rauement & Ridkeit & rauenure & Ridam \\
\hline draiteux & Rachtbar & draitate & Rachtmen \\
\hline julion & Saktung & julache & Saktmen \\
\hline satlion & Sardung & satlenule & Sarducht \\
\hline trisorion & Schetzung & trisorisse & Schetzarf \\
\hline selpion & Sintung & selpare & Sintau \\
\hline pisfement & Smurkeit & pisfenure & Smurnauf \\
\hline piurrement & Steunung & piurrenule & Steunam \\
\hline fronseux & Stirmbar & fronsaste & Stirmatz \\
\hline jaurable & Tafbar & jaurouse & Tafucht \\
\hline tupisable & Teplichbar & tupisisse & Teplichatz \\
\hline teblement & Teschkeit & teblenure & Tescharf \\
\hline pomeux & Tolfbar & pomare & Tolfekt \\
\hline tunfelion & Tunfelung & tunfelipe & Tunfelau \\
\hline muleux & Wardbar & muluque & Wardekt \\
\hline monpement & Woltkeit & monpenure & Woltekt \\
\hline veltable & Wisdbar & velterge & Wisducht \\
\hline bleguement & Wetzkeit & bleguipe & Wetzarf \\
\hline loufeux & Wolphaft & loufouse & Wolpat \\
\hline mapieux & Wosthaft & mapige & Wostpern \\
\hline dunteur & Zuhner & duntaste & Zuhnarf \\
\hline telpsable & Zeilbar & telpsouse & Zeilam \\
\hline tenfement & Zelpkeit & tenfenure & Zelpat \\
\hline praineux & Zighaft & prainaste & Zigat \\
\hline
\end{tabular}

Words

Morphologically simple

Morphologically complex

French

German

French

German 


\begin{tabular}{|c|c|c|c|}
\hline fourmi & Ameise & boulanger & Bäcker \\
\hline asphalte & Asphalt & traitement & Behandlung \\
\hline banane & Banane & décision & Bescheid \\
\hline basilic & Basilisk & serviteur & Diener \\
\hline coutume & Brauch & stupidité & Dummheit \\
\hline brosse & Bürste & existence & Existenz \\
\hline diamant & Diamant & forteresse & Festung \\
\hline douche & Dusche & pêcheur & Fischer \\
\hline succès & Erfolg & chercheur & Forscher \\
\hline flamme & Flamme & liberté & Freiheit \\
\hline girafe & Giraffe & coiffure & Frisur \\
\hline guitare & Gitarre & jeunesse & Jüngling \\
\hline auberge & Herberge & maladie & Krankheit \\
\hline collègue & Kollege & artiste & Künstler \\
\hline commode & Kommode & puissance & Leistung \\
\hline contact & Kontakt & clairière & Lichtung \\
\hline contrôle & Kontrolle & menteur & Lügner \\
\hline concert & Konzert & directeur & Manager \\
\hline griffe & Kralle & humanité & Menschheit \\
\hline perruque & Perücke & musicien & Musiker \\
\hline flaque & Pfütze & beauté & Schönheit \\
\hline plaque & Platte & sécurité & Sicherheit \\
\hline puzzle & Puzzle & règlement & Siedlung \\
\hline pyramide & Pyramide & gagnant & Sieger \\
\hline soldat & Soldat & joueur & Spieler \\
\hline cigogne & Storch & position & Stellung \\
\hline talent & Talent & viseur & Sucher \\
\hline tomate & Tomate & entraîneur & Trainer \\
\hline triomphe & Triumph & formation & Training \\
\hline cigare & Zigarre & sagesse & Weisheit \\
\hline
\end{tabular}

